\title{
PELATIHAN KONSELING GIZI IBU HAMIL BAGI BIDAN DESA SEBAGAI PENGUATAN ASUHAN KEHAMILAN DALAM MENCEGAH ANEMIA DI WILAYAH PUSKESMAS JATINANGOR
}

\author{
Sefita Aryuti Nirmala, Dini Saraswati Handayani, Lina Rahmiati, Ariyati Mandiri, \\ Irna Kurnia Aprillani, Khalidatunnur Andriani, dan Tina Dewi Judistiani \\ Prodi Kebidanan, Departemen Ilmu Kesehatan Masyarakat, Fakultas Kedokteran, Universitas Padjadjaran \\ E-mail: sefita@unpad.ac.id / sf.nirmala@gmail.com
}

\begin{abstract}
ABSTRAK. Data berbagai penelitian menunjukkan bahwa masih banyak kejadian anemia pada ibu hamil. Di Kecamatan Jatinangor hasil penelitian yang dilakukan oleh Susanti, ddk tahun 2017 menunjukkan terdapat 21,9\% ibu hamil dengan anemia. Pencegahan anemia pada ibu hamil dapat dilakukan dengan mengatur pola makan yang baik dan benar. Masih banyak ibu hamil yang belum mengetahui agar asupan makanan dapat memenuhi kebutuhan tubuh serta mencegah kejadian anemia. Bidan memiliki kewenangan dalam memberikan asuhan kehamilan termasuk memberikan konseling mengenai pola makan yang baik dan benar. Oleh karena itu diperlukan pelatihan konseling gizi ibu hamil bagi bidan agar meningkatkan kualitas asuhan kehamilan. Sasaran pelatihan ini adalah bidan desa di Puskesmas Jatinangor. Metode pelatihan dilakukan dengan metode ceramah, tanya jawab dan role play praktik konseling. Hasil dari pre dan post test menunjukkan peningkatan nilai pengetahuan bidan yaitu dari rata-rata nilai pre test yaitu 15,54 pada rata-rata nilai post test menjadi 18,81, maka dapat disimpulkan bahwa tujuan dari pelatihan ini tercapai.
\end{abstract}

Kata kunci: konseling, gizi, ibu hamil, anemia

ABSTRACT. Data from various studies showed that there were still many cases of anemia in pregnant women. In Jatinangor the results of research by Susanti, at all in 2017 showed that there were 21.9\% of pregnant women with anemia. Prevention of anemia in pregnant women can be prevented by a good and correct diet. There are still many pregnant women who do not know what kinds of food can be fulfilling the body needs. Midwives have the authority to provide pregnancy care including providing counseling of good and right diet. Therefore nutrition training about pregnant women is needed for midwives to improve the quality of care for pregnancy. The subject of this training wa midwives assigned in the villages at the Jatinangor Community Health Center. The training method is conducted by the lecture method, discussion and role play counseling practices. The results of the pre and post test showed an increased in the value of knowledge of midwives, namely from the average pre test value of 15.54 to the average post test score of 18.81, it can be concluded that the purpose of this training was achieved.

Key words: traning, nutrition, pregnant women, anemia

\section{PENDAHULUAN}

Tidak semua ibu hamil dan keluarganya mendapatkan pendidikan dan koseling kesehatan yang memadai, terutama tentang kehamilan dan upaya menjaga agar kehamilan tetap sehat dan berkualitas. Kunjungan pemeriksaan kehamilan semestinya menjadi kesempatan tenaga kesehatan untuk memberikan informasi kesehatan esensial bagi ibu hamil dan keluarga (Praworohardjo, 2009). Salah satu asuhan kehamilan yang diberikan oleh bidan agar ibu dan janin selalu dalam keadaan sehat dan sejahtera adalah dengan memberikan asuhan pola makan yang baik dan benar.

Gizi merupakan faktor penting yang berpengaruh terhadap kualitas seseorang termasuk ibu hamil. Berbagai penelitian telah mengungkapkan bahwa malnutrisi yang terjadi padaawal kehamilan mempengaruhi perkembangan dan kapasitas embrio untuk bertahan hidup. Kekurangan gizi pada ibu hamil dapat menyebabkan Berat Bayi Lahir Rendah (BBLR), terhambatnya pertumbuhan otak janin dan bayi lahir pendek. Melalui pola makan yang baik benar selain kebutuhan gizi bagi ibu terpenuhi, kebutuhan gizi bagi janin juga terpenuhi sehingga pertumbuhan dan perkembangan berjalan dengan normal sesuai dengan usia kehamilan. Masalah yang sering ditemui oleh ibu hamil adalah kesulitan makan dikarenakan terdapatnya mual dan muntah.
Penelitian yang dilakukan oleh Zuhairini, dkk di Jatinangor tahun 2016 didapatkan bahwa indeks massa tubuh ibu hamil pada 90 respoden rata-rata adalah $23,89\left(\mathrm{Kg} / \mathrm{m}^{2}\right)$ dengan nilai minumum $16,51\left(\mathrm{Kg} / \mathrm{m}^{2}\right)$ dan nilai maksimaum 40,89 (Kp/ $\left.\mathrm{m}^{2}\right)$. Pada awal kehamilan, asupan energi rata-rata perhari sudah cukup tinggi dengan komposisi nutrien sumber energi dari karbohidrat $66 \%$, lemak $32 \%$ dan protein $12 \%$. Indeks massa tubuh, massa lemak dan air tubuh total (ATT) berhubungan sangat bermakna dengan kenaikan berat badan ibu selama hamil (Zuhairini, Kasmanto, \& Nugraha, 2016).

Apabila kebutuhan gizi ibu hamil tidak terpenuhi maka dapat timbul gangguan gizi dan penyulit kehamilan. Salah satunya adalah kejadian anemia. Ibu hamil sangat rentan dengan terjadinya anemia. Perubahan fisiologis yaitu adanya proses haemodilusi mengakibatkan ibu hamil akan mengalami penurunan kadar haemogloblin dalam tubuhnya. Volume darah ibu meningkat selama trimester pertama. Peningkatan terjadi paling cepat pada trimester kedua, kemudian naik pada tingkat yang jauh lebih lambat pada trimester ketiga Kemudian volume darah akan stabil pada selama beberapa minggu kehamilan (Astuti, Susanti, Nurparidah, \& Mandiri, 2017). Hasil penelitian yang dilakukan oleh Judistiani, dkk pada empat kota di Jawa Barat mulai tahun 2016 hingga 2017 dari 191 ibu hamil 7,5\% diantaranya mengalami anemia dan proporsi kejadian anemia meningkat pada setiap trimesternya 
(Judistiani et al., 2018). Penelitian lainnya yang di lakukan oleh Susanti, dkk di Jatinangor 21,9\% ibu hamil mengalami anemia (Susanti et al., 2017).

Kecamatan Jatinangor dengan wilayah seluas 262 $\mathrm{km}^{2}$ terdiri dari 12 desa, memiliki 2 puskesmas yaitu Puskesmas Jatinangor dan Puskemas Cisempur. Terdapatnya perguruan tinggi negeri di jatinangor menjadikan kecamatan ini tumbuh dan berkembang dengan pesat. Sebelumnya kecamatan Jatinangor hanya memiliki satu puskesmas, namun mulai februari 2018 memiliki 2 puskesmas yaitu Puskesmas Jatinangor dan Puskesmas Cisempur. Puskesmas Jatinangor dengan wilayah 7 desa yaitu Hegarmanah, Cibeusi, Cileles, Cilayung, Cipacing, Sayang dan Cikeruh. Sedangkan untuk Puskesmas Cisempur membawahi wilayah desa Cisempur, Cintamulya, Jatimukti, Jatiroke, dan Mekargalih. Pada setiap desa ditugaskan 2 orang bidan desa.

Program pengabdian masyarakat sebelumnya telah dilakukan oleh Perdana, dkk tahun 2017 di desa Cintamulya. Hasil yang didapatkan melalui metode kualitatif diperlukan penguatan pada ibu yaitu dengan penyuluhan (Perdana \& Herawati, 2018). Tentunya sebelum melakukan penyuluhan diperlukan penguatan bagi orang yang memberikan materi atau diperlukan terlebih dahulu pelatihan bagi yang akan memberikan materi. Studi lainnya yang dilakukan oleh Komariah, dkk di Kecamatan Jatinangor bahwa ibu-ibu yang mendapatkan pelatihan mereka bersedia untuk menularkan pengetahuan yang didapatkan kepada yang lain (Komariah \& Wiyoto, 2018). Sehingga tepat apabila dilakukan pelatihan konseling gizi ibu hamil bagi bidan sebagai penguatan dalam memberikan asuhan kehamilan.

Sebagai usaha membantu peningkatan kualitas sumber daya bidan di Puskesmas Jatinangor dalam memberikan asuhan pada ibu hamil untuk mencegah terjadinya anemia, maka dilakukan pelatihan konseling gizi ibu hamil. Hasil penelitian yang dilakukan oleh Bara, dkk menunjukkan bahwa ibu dengan anemia mengalami peningkatan berat badan dan peningkatan kadar hemogloblin setelah mendapatkan konseling dari pada ibu dengan anemia yang tidak mendapat konseling (Bara, Fanny, \& Wijayanegara, 2015). Pelatihan konseling gizi ini bertujuan untuk memberikan penguatan asuhan kehamilan pada bidan mengenai pola makan yang baik dan benar bagi ibu hamil. Diharapkan dengan melakukan pola makan yang baik dan benar ibu hamil dapat terhindar dari anemia. Penelitian yang dilakukan oleh Hapzah, dkk menunjukkan bahwa pada kelompok ibu yang mendapatkan konseling selain meningkatkan kadar hemogloblin juga terdapat konsumsi kalori meningkat secara bermakna (Hapzah, Hadju, \& Sirajuddin, 2013).

\section{METODE}

Sebelum tim melakukan pelatihan konseling pada bidan desa di wilayah Puskesmas Jatinangor, terlebih dahulu tim melalukan Training of Trainer (TOT) tentang pelatihan konseling gizi ibu hamil dengan narasumber ahli gizi DR. Rita Ramayulis, DCN, M.Kes. TOT dilakukan selama dua hari dengan peserta adalah tim yang akan melakukan pelatihan bagi bidan. Tujuan dari TOT ini adalah untuk melakukan penguatan pada tim tentang kebutuhan gizi ibu hamil serta bagaimana pola makan yang baik dan benar sehingga terpenuhinya kebutuhan gizi dan mencegah kejadian anemia pada ibu hamil. Kemudian setelah mengikuti TOT tersebut, tim peneliti merumuskan materi yang akan disampaikan pada pelatihan bagi bidan. Materi yang dirumuskan disesuaikan dengan kewenangan bidan dalam memberikan asuhan kehamilan.

Metode yang digunakan pada pelatihan konseling gizi ibu hamil ini adalah dengan ceramah, diskusi dan melakukan role play praktik konseling. Materi ceramah yang diberikan berupa penilaian status gizi pada ibu hamil, kebutuhan zat gizi ibu hamil dan pola makan yang benar, pencegahan anemia pada ibu hamil, komunikasi dan konseling, persiapan konseling pada ibu hamil. Sebelum materi diberikan peserta mendapatkan pre test yang bertujuan agar tim pelatih mengetahui sejauh mana ilmu tentang konseling gizi ibu hamil yang dimiliki oleh peserta.

Kemudian dilanjutkan dengan penyampaian materi dengan menggunakan metode ceramah, tanya jawab dan menggali pengalaman peserta dalam memberikan konseling gizi ibu hamil. Setelah seluruh materi selesai maka sesi selanjutnya adalah dengan melakukan role play praktik konseling. Peserta saling berpasangan, satu orang berperan sebagai bidan dan satu orang lagi berperan sebagai ibu hamil sesuai dengan kasus ibu hamil yang diberikan. Variasi kasus digunakan dalam role play praktik konseling agar peserta merasakan tantangan dalam memberikan konseling kebutuhan nutrisi ibu hamil. Sebelum pelatihan ditutup peserta diukur kembali tingkat pengetahuan konseling gizi ibu hamil dengan melakukan post test. Peserta yang mengikuti pelatihan ini mendapatkan sertifikat dengan capaian SKP IBI 2 SKP bagi peserta, 2 SKP bagi pelatih dan 1 SKP bagi panitia.

\section{HASIL DAN PEMBAHASAN}

Strategi yang dilakukan agar Pelatihan ini berjalan dengan lancar adalah pada tahap awal tim mengadakan rapat koordinasi dengan Kepala Puskesmas Jatinangor dan Bidan Koordinator. Disampaikan pada rapat koordinasi tersebut data yang menunjukkan kejadian anemia pada ibu hamil terutama Jawa Barat dan Jatinangor. Kejadian anemia pada ibu hamil dapat dicegah salah satunya dengan cara memberikan asuhan yang kuat untuk memperbaiki pola makan ibu hamil. Tim menyampaikan program pengabdian masyarakat yang dilakukan di Puskesmas Jatinangor yaitu berupa pelatihan konseling gizi bagi bidan desa di puskesmas Jatinangor. Pelatihan tersebut disambut baik oleh pihak puskesmas dan pelaksanaan dapat dilakukan di puskesmas jatinangor.

Tahap kedua adalah mematangkan materi pelatihan yang sebelumnya telah dibuat melalui hasil TOT tim 
pelatih dengan mengundang narasumber ahli gizi. Kemudian agar materi perlatihan diakui secara legal, tim mengajukan permohonan pada Ikatan Bidan Indonesia Pengurus Daerah Jabar (IBI PD Jabar) agar pelatihan tersebut mendapat SKP. Kemudian tahap selanjutnya adalah melakukan pelatihan.

Pelatihan yang dilakukan selama dua hari ini dikuti oleh 11 bidan desa sebagai peserta bertempat di Aula Puskesmas Jatinangor. Antusias para peserta ditunjukkan dengan diskusi interaktif berdasarkan pengalaman yang pernah didapatkan selama menjadi bidan desa dalam memberikan asuhan pada ibu hamil. Tantangan yang dirasakan bidan desa selama memberikan asuhan pada ibu hamil adalah kondisi geografis desa, sosial budaya yang ada, sampai dengan tingkat pendidikan ibu menjadi faktor yang berpengaruh dalam tercapaiannya tujuan asuhan kehamilan.

Sebagai tolok ukur keberhasilan pelatihan, dilakukan penilaian pada pre dan post test dengan jumlah soal masing-masing tes adalah 20 butir. Dalam buku Teknik Penyusunan Instrumen Penelitian oleh Eko Putro Widoyoko untuk mengumpulkan data tentang hasil belajar dapat dilakukan dengan menggunakan instrument berupa tes. Tes merupakan salah satu alat untuk melakukan pengukuran. Tes merupakan bagian tersempit dari penilaian. Menurut Djemari (2008:67) tes merupakan salah satu cara untuk menaksir besarnya kemampuan seseorang terhadap stimulus atau pertanyaan. Respon peserta terhadap sejumlah pertanyaan maupun peryataan menggambarkan kemampuan dalam bidang tertentu (Widoyoko, 2012). Berikut ini gambar grafik hasil penilaian pre dan post test Pelatihan Konseling Gizi Ibu Hamil:

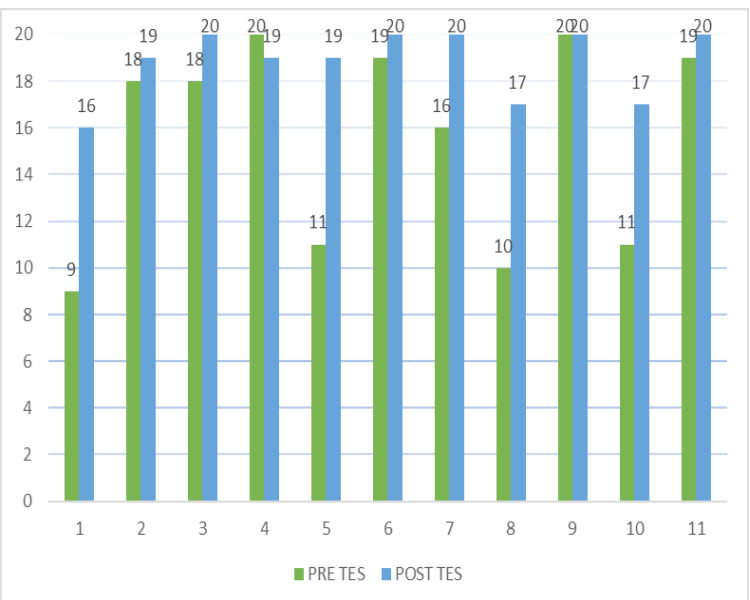

Gambar 1. Hasil pre dan post test Pelatihan Konseling Gizi Ibu hamil pada Bidan Desa Puskesmas Jatinangor

Pada grafik 1 tampak kenaikan nilai pre dan post test setiap peserta pelatihan. Hal tersebut menunjukkan bahwa terdapat peningkatan pengetahuan peserta dari stimulus yang diberikan berupa materi pelatihan. Kenaikan nilai peserta dengan katergori nilai rata-rata, tertinggi dan terendah dapat dilihat pada tabel 1.
Tabel 1. Kategori penilaian rata-rata, nilai tertinggi dan nilai terendah hasil pre dan post test

\begin{tabular}{ccc}
\hline Kategori penilaianan & Post test & Post test \\
\hline Nilai tertinggi & 20 & 20 \\
Nilai terendah & 9 & 16 \\
Rata-rata & 15,54 & 18,81 \\
\hline
\end{tabular}

Nilai tertinggi pada pre test dan post test yaitu 20. Jumlah yang mendapatkan nilai tertinggi pada post test yaitu 4 orang, namun sebelumnya pada pre test 3 orang memiliki nilai kurang dari 20 dan 1 orang yang mendapatkan nilai 20. Secara keseluruhan peserta mengalami peningkatan nilai yaitu dengan nilai ratarata pada post test adalah 15,54 kemudian hasil post test menjadi 18,81 .

\section{SIMPULAN}

Pelatihan Konseling Gizi Ibu Hamil Bagi Bidan di Puskesmas Jatinangor merupakan salah satu bentuk kegiatan pengabdian masyarakat sebagai wujud dari Tri Dharma Perguruan Tinggi. Harapan yang sangat besar bahwa dengan dilakukannya pelatihan ini dapat memperkuat layanan asuhan kehamilan yang diberikan oleh bidan desa untuk mencegah keajadian anemia pada ibu hamil.

Berdasarkan hasil penilaian pre dan post test pada pelatihan tersebut didapatkan kenaikan tingkat pengetahuan bidan dalam konseling gizi ibu hamil sehingga dapat disimpulkan bahwa telah tercapainya tujuan pelatihan. Pengetahuan yang didapatkan bidan dalam pelatihan diperlukan bidan untuk dapat menjawab tantangan yang dihadapi dalam memberikan layanan asuhan kehamilan. Sehingga kualitas asuhan kehamilan terjamin serta ibu dan janin selalu dalam keadaan sehat.

\section{UCAPAN TERIMAKASIH}

Terlaksananya Pelatihan Konseling Gizi Ibu Hamil bagi Bidan ini berkat bantuan dari berbagai pihak. Ucapan terima kasih kami sampaikan kepada Dekan Fakultas Kedokteran Universitas Padjadjaran yaitu med. Setiawan, dr., AIFO. yang telah memberikan kesempatan kepada kami untuk melakukan pengabdian masyarakat. Kepada Ketua Academic Grant Leadership "Peran Vitamin D dalam menurunkan Angka Kematian Ibu dan Anak" di Jawa Barat yaitu Prof. DR. Budi Setiabudiawan, dr., Sp.A(K), M.Kes. berkat dukungan beliau pengabdian masyarakat ini menjadi bagian dari pengabdian masyarakat yang dilakukan oleh tim ALG. Kepada Kepala Puskesmas Jatinangor dan Bidan Koordinator yang telah memberikan kepercayaan untuk mengadakan pelatihan di Puskesmas Jatinangor. Serta apresiasi tim kepada para sejawat bidan desa di wilayah Puskesmas Jatinangor yang telah berpartisipasi mengikuti pelatihan ini. Tak luput tim juga menghaturkan terima kasih kepada pihak-pihak 
yang telah berkontribusi dalam kegiatan pelatihan ini dan tidak dapat disebutkan satu persatu. Semoga pelatihan ini memberikan mashalat bagi kesehatan dan kesejahteraan ibu dan anak di wilayah Puskesmas Jatinangor.

\section{DAFTAR PUSTAKA}

Astuti, S., Susanti, A. I., Nurparidah, R., \& Mandiri, A. (2017). Asuhan Ibu dalam Masa Kehamilan. (E. K. Dewi \& R. Astikawati, Eds.). Penerbit Erlangga.

Bara, F. T., Fanny, L., \& Wijayanegara, H. (2015). Pengaruh Konseling Gizi Ibu Hamil dengan Anemia terhadap Status Gizi di Kecamatan Minasatene dan Kecamatan Pangkajene Kabupaten Pangkajene. Ilmiah Kesehatan Diagnosis, 6(2), 235-262.

Hapzah, Hadju, V., \& Sirajuddin, S. (2013). Pengaruh Konseling Gizi dan Suplementasi Gizi Mikro. Media Gizi Masyarakat, 2(2), 64-70.

Judistiani, R. T. D., Gumilang, L., Nirmala, S. A., Irianti, S., Wirhana, D., Permana, I., ... Setiabudiawan, B. (2018). Association of colecalciferol, ferritin, and anemiaamong pregnantwomen: Result fromcohort study on Vitamin D status and its impact during pregnancy and childhood in Indonesia. Anemia, 2018. https://doi.org/10.1155/2018/2047981
Komariah, N., \& Wiyoto, Y. (2018). Upaya Pemberdayaan Perempaun Melalui Pelatihan Literasi Informasi Kesehatan pada Ibu-ibu Kader PKK. Dharmakarya, 7(1), 26-31.

Perdana, F., \& Herawati, H. (2018). Upaya Meningkatkan Kesehatan Ibu dan Anak Melalui Literasi Kesehatan Dan Hibah Buku Di Desa Cintamulya RW 05 Jatinangor. Dharmakarya, 7(1), 6-10.

Praworohardjo, S. (2009). Ilmu Kebidanan. (A. B. Saifuddin, Ed.) (kedua). Jakarta: PT. Bina Pustaka.

Susanti, A. I., Sarihatmajda, E., Winarno, G., Sugianli, A. K., Susanto, H., \& Panigoro, R. (2017). Low Hemoglobin among Pregnant Women in Midwives Practice of Primary Health Care, Jatinangor, Indonesia: Iron Deficiency Anemia or $\beta$ Thalassemia Trait? Anemia. Anemia, 2017. https://doi.org/10.1155/2017/6935648

Widoyoko, E. P. (2012). Tekini Penyusunan Instrumen Penelitian (Pertama). Yogyakarta: Pustaka Pelajar.

Zuhairini, Y., Kasmanto, H., \& Nugraha, G. I. (2016). Indeks Massa Tubuh Awal Kehamilan Ibu sebagai Indikator yang paling berperan terhadap Kenaikan Berat Badan Ibu selama hamil. Majalah Kedokteran Bandung, 48(3), 171-175. Retrieved from https://doi.org/10.15395/mkb.v48n3.847 